\title{
Vozes diluídas no plágio: a (des)construção autoral entre alunos de licenciaturas ${ }^{1}$
}

\author{
Wagner Teixeira Dias * , Zena Winona Eisenberg * * \\ http://dx.doi.org/10.1590/0103-7307201507602
}

\section{Resumo}

Tendo como foco os trabalhos de pesquisa realizados por alunos de licenciaturas como instrumento avaliativo, apresentam-se aqui implicações do plágio na diluição da autoria. Por meio de entrevistas semiestruturadas com 30 licenciandos e 09 professores de licenciaturas, aferiu-se como o plágio é compreendido e como a pesquisa tem sido gerenciada nos cursos de licenciatura. Constatou-se que a orientação e o ensino de pesquisa têm sido deficitários e que os licenciandos não são formados para pesquisar ou ensinar seus futuros alunos a investigar. Assim, tanto se aponta para a necessidade de uma reflexão que dê ênfase à sensibilização para questões éticas, de orientação e de sanção para os casos de reincidência no plágio, como também, e de forma propositiva, debate-se a importância da construção da autoria na escola. Apoiados na teoria bakhtiniana, acredita-se no diálogo entre vozes polifônicas para promover autorias e construção de conhecimento.

Palavras-chave: autoria, plágio, formação de professores
* Pontifícia Universidade Católica do Rio de Janeiro, Rio de Janeiro, RJ, Brasil. wagnertedi@yahoo.com.br

* * Pontifícia Universidade Católica do Rio de Janeiro, Rio de Janeiro, RJ, Brasil. zwe@puc-rio.br
1. A Dissertação de Mestrado que deu origem a este artigo contou com 0 apoio das agências financiadoras CNPq e FAPERJ. 


\title{
Diluted Voices through Plagiarism: the (De)Construction of Authorship among Undergraduate Students in Teacher's Education
}

\begin{abstract}
Focusing on research as an assessment tool with undergraduate students, we present implications of plagiarism in the dilution of authorship. Through semi-structured interviews with 30 students and 09 professors, we measure how plagiarism is understood and how the research process has been conducted. We found that guidance and teaching of research have been timid and that undergraduate students are not trained to do research or to teach how their future students how to investigate. Thus, we point to the need for a reflection that emphasizes not only awareness of ethical issues, guidance and sanction for cases of recurrent plagiarism, but also we propose a debate on the importance of the construction of authorship in school. Based on Bakhtinian theory, we believe in dialogue among polyphonic voices in promoting authorship and knowledge construction.
\end{abstract}

Keywords: authorship, plagiarism, teacher training 


\section{Introdução}

O fenômeno do plágio acadêmico tem movimentado professores, universidades e órgãos de fomento à pesquisa em todo o mundo nos últimos anos. Embora o tema possa ser abordado em diversos campos - artes, comunicação, Direito, ciência e tecnologia - quando se refere à Educação e, principalmente, aos cursos de formação de professores, a preocupação se intensifica. Trata-se de refletir acerca das bases da construção do saber, de modo a tentar compreender o preocupante quadro de alunos que chegam aos cursos de licenciatura em universidades públicas, privadas ou confessionais, apresentando pouco ou nenhum domínio de processos investigativos ético-responsáveis, passam por esses cursos, repetindo um histórico de incoerências, e retornam à escola como lentes, reforçando um ciclo de diluição autoral.

Esse panorama clássico fortalece a hipótese de que meras buscas superficiais em livros, artigos, internet, ou ainda a cópia desses materiais, muitas das vezes, são consideradas como pesquisas. Esse fato banaliza a importância da atividade investigativa, tornando-a, de modo simplista, apenas um instrumento para a produção de notas/graus, estimulando concorrências e rankings, em detrimento da busca do aprendizado.

O caso se agrava quando toda uma gama de fontes é utilizada sob o subterfúgio do plágio. Nesse caso, os textos tornam-se desprovidos de autorias ético-responsáveis, evidenciando a voz do outro e ofuscando o que deveria ser a exposição de concepções críticas próprias do pesquisador sobre um determinado fenômeno.

Desse modo, alguns questionamentos norteiam essa discussão: como pesquisar ou ensinar pesquisa, se a formação para tal tem sido deficitária nos cursos de licenciatura? Se o licenciando não aprendeu a tecer seu próprio caminho autoral e de construção do conhecimento por meio de investigações acadêmicas, estará ele apto a mediar processos investigativos de seus futuros alunos? E a universidade? Como ela deve atuar para enfrentar os problemas em foco?

Partindo dessas proposições e ancorando-nos nos dados produzidos para ${ }^{2}$ nossa dissertação de Mestrado em Educação, procuramos com este artigo: primeiramente, situar o leitor no entendimento dos conceitos de autoria e plágio e sua tensa relação fronteiriça. Na sequência, apresentar a síntese de nossa metodologia de pesquisa e, em um terceiro momento, ilustrar, com trechos de entrevistas, as afirmações tecidas a partir dos resultados empíri-

2. 0 uso da primeira pessoa é proposital, para marcar a autoria, uma vez que abordamos possibilidades de construção autoral. Assim, neste caso específico, a orientadora da dissertação, Zena, é considerada coautora. 
cos. Por fim, traçamos considerações acerca do tema abordado, enfocando a necessidade de diálogos acadêmicos acerca de autoria e plágio no âmbito dos cursos de formação de professores. Tais diálogos se fazem necessários, por entendermos que, apenas a partir de debates entre universidades, seus professores e seus licenciandos, será possível minimizar a realização do plágio e fomentar uma formação para a pesquisa de modo profícuo e academicamente íntegro.

\section{Plágio: algumas definições}

O primeiro passo, ao se discutir plágio, é a compreensão de suas definições e suas relações com o conceito de autoria. Essas implicações não se inserem apenas no contexto semântico. A questão cultural também deve ser considerada, já que existem países, como, por exemplo, a China, influenciada pela cultura confucionista, onde a cópia pode ser percebida de modo avesso aos países ocidentais. Diante desses vieses de abordagem, listamos a seguir alguns entendimentos sobre plágio.

Do ponto de vista etimológico, o vocábulo “plágio”, na visão de Machado (1967, p.1831), traz a seguinte acepção:

Plágio, s. Do gr. Plágios, “oblíquo, que não está em linha recta, que está de lado, de esguelha; que apresenta o flanco, transversal, falando especialmente de uma linha de batalha, de um exército, de uma esquadra; fig. Que usa meios oblíquos, equívoco, pérfido, velhaco; em gramática, ptóseis, plágioi, os casos oblíquos, isto é, genitivo dativo em oposição ao caso directo (ptôsis orthé), pelo lat. Plagiu-, o crime do plagiário". / Plagiar, v. Do lat. Plagiare, "roubar, esbulhar". ... / Plagiário, adj. Do lat. plagiariu-, "plagiário, o que rouba escravos; o que vende ou o que compra como escravo uma pessoa livre; fig. Plagiário (falando dum autor)". Séc. XVIII: E a cômica Thalia te condemna / Dos plagiários vis a andar na lista...

O dicionário Aurélio, da Língua Portuguesa, define: “Plágio: sm. Ato ou efeito de plagiar. / Plagiar: v.t.d. 1. Apresentar como seu (trabalho intelectual de outrem). 2. Imitar (obra alheia)" (Ferreira, 2001, p. 538).

Leite (2009) diz que, costumeiramente, o plágio tem a noção geral de ser “o uso das palavras ou textos de outrem, sem informar de quem eles são ou qual a fonte de onde foram tirados" (p. 20). Partindo dessa proposição, o autor delineou a seguinte definição: 
a cópia, dissimulada ou disfarçada, do todo ou de parte da forma pela qual um determinado criador exprimiu as suas ideias, ou seja, da obra alheia, com a finalidade de atribuir-se a autoria da criação intelectual e, a partir daí, usufruir o plagiador das vantagens advindas da autoria de uma obra. Podemos também definir plágio como o ato de apropriar-se da composição, ideias ou expressão de outrem, de partes ou passagens de obras alheias, apresentando-as como produto da intelectualidade daquele que pratica o ato expropriatório (p. 21).

Orlandi (1996) apresenta uma reflexão que alude à diluição da voz autoral por meio do ato ilícito e à manutenção do nível da autoria, segundo a autora, com o plágio,

o plagiador silencia seu trajeto, ele cala a voz do outro que ele retoma. Não é um silenciamento necessário, mas imposto, uma forma de censura: o enunciador que repete e apaga, toma o lugar do autor indevidamente, intervém no movimento que faz a história, a trajetória dos sentidos (nega a identidade ao outro e em consequência, trapaceia com a própria) (p. 72).

Park (2003), por sua vez, mostra que o plágio, em diversas áreas do conhecimento, pode ser caracterizado como sendo um câncer, um pecado - um deslize técnico, dentro da área literária ou linguística; bem como um crime, sob a égide do Direito.

As definições apresentadas permitem visualizar a existência de alguns diferenciais que dificultam traçar de modo uno o conceito de plágio. No entanto, todas as acepções tocam na questão da apropriação da voz ou da ideia de outrem de modo desautorizado. Diante disto, o plagiário, seja em que circunstância for, intencional com caráter de dissimulação - ou não intencionalmente - por um deslize técnico, ou por desinformação - acaba por se passar por outro, graças à grafia do texto ou a outra forma de materialização da ideia, para se expressar. De um modo ou outro, o plágio acaba por se configurar, o que faz com que se anule a autoria, uma vez que outras vozes, manipuladas sem a devida referência, diluem o discurso de quem propõe um enunciado, ocorrendo o que Leite (2009) chama de "sequestro da expressão".

Ainda nos referindo às difusas conceituações de plágio, parece consenso que todos aqueles que se atêm ao estudo do tema entendem que ele é moral e eticamente inaceitável, uma vez que não dar o devido crédito à voz de outrem configura roubo, apropriação indevida, ou sequestro da expressão, como já dito anteriormente. 
Muitas práticas são listadas por estudiosos do tema (Barbastefano \& Souza, 2007; Krokoscz, 2012; Leite, 2009;Vasconcellos, 2007) como sendo plágio e, diante da difusa possibilidade de definições, sintetizamos aquelas que nos parecem as mais relevantes: a) cópia integral ou parcial de obra alheia sem os devidos créditos; b) paráfrases não referenciadas - quando licenciandos modificam um pensamento de um autor, sem referenciá-lo; c) mistura de trechos de enunciados, de modo a ludibriar o leitor, não the permitindo reconhecer as origens criativas do texto plagiado e levando-o a entender que o plagiador é o verdadeiro dono das partes copiadas, direta ou indiretamente; d) autoplágio - quando um autor propõe seus textos já publicados, sem alusão aos trabalhos anteriores, criando a expectativa de algo inovador, mas deixando de contribuir com novas discussões, enganando o leitor, que acredita estar diante de algo inédito. 0 autoplágio implica graves problemas de ordem ética e material, principalmente se pensarmos na questão editorial e nos acordos de ineditismo.

Assim, compreendendo que, se o plágio se encontra em uma região fronteiriça com o conceito de autoria, dar foco à construção de licenciandos autores pode ser um caminho profícuo no combate a posturas antiéticas em pesquisa. Pressupomos que quem autora não necessita do recurso da cópia de discursos de outrem.

No item seguinte, apresentamos algumas definições de autoria e enfatizamos caminhos para a construção de autores, nos moldes do pensamento de Mikhail Bakhtin.

\section{A fronteira entre autoria e plágio}

São múltiplas as conotações que o conceito de autoria carrega, desde sua base etimológica, passando por preceitos filosóficos, linguísticos e literários, podendo ser ajustado, ou compreendido, de acordo com o ângulo proposto para a observação.

Etimologicamente, Machado (1967) define autor da seguinte forma:

Autor, s. Do lat. Auctore-, “o que aumenta, que faz avançar, produzir; o que aumenta a confiança; fiador; que confirma autoridade, fonte; modelo, senhor, autoridade; fonte histórica; o que obriga a agir; conselheiro, instigador, promotor; criador, iniciador, fundador, autor; o que faz (compõe) uma obra, escritor". Séc. XV: “Começo este livro nom como autor e achador das cousas em elle contheudas" ... (p. 355).

O dicionário Aurélio diz: “Autoria: sf. Condição de autor. / Autor: (ô) sm. 1. A causa 
principal, a origem de. 2. Criador de obra artística, literária ou científica. 3. Aquele que intenta demanda judicial” (Ferreira, 2001, p. 77).

Dificilmente o tema da autoria será abordado sem contar com as colaborações de Foucault, Barthes, Bakhtin. Todas essas referências dão corpo às discussões que tangem o campo da literatura, da filosofia do discurso.

Foucault (1992/2009), em seus estudos, aponta para o que ele denominou de “função-autor". Em linhas gerais, essa função-autor não se refere ao fato de se correlacionar uma construção textual, uma obra, um discurso a um determinado indivíduo e atribuir-lhe a autoria. Para ele, a função-autor estabelece uma relação direta dos modos de uma obra funcionar, penetrar, circular e agir dentro de um dado grupo social.

Barthes (2004), assim como Foucault, descentraliza a atenção dada a um indivíduo, invertendo o entendimento autoral. Para ele, o autor nada mais é que o resultado do ato da escrita, partindo do ideal de que tal autor sempre irá descrever em suas obras algo já dito, já descrito, já evidenciado, tornando-se, dessa forma, aquele que sincretiza discursos já proferidos.

São, no entanto, as proposições do filósofo da linguagem Mikhail Bakhtin (1995, 2010a, 2010b) as que dialogam de modo mais próximo com as nossas discussões. 0 entendimento desse autor acerca de autoria nos serve de âncora para o debate que trazemos à baila, principalmente por meio dos conceitos de polifonia e dialogismo.

Isso quer dizer que se compreendemos que a autoria em um trabalho investigativo de cunho científico se faz por meio do diálogo entre ideias e autores, estamos operando com o caráter dialógico e polifônico de um texto como o de pesquisa. Neste caso, pesquisar, especialmente no âmbito das Ciências Humanas, como propõe Amorim (2004), estabelece uma relação de alteridade na qual o pesquisador se preenche do outro e, concomitantemente, complementa este outro por intermédio do diálogo de ideias. Nesse diálogo, muitas são as vozes, as citações do discurso de outrem que, articuladas, compõem o todo do fazer autoral.

Por essa via, os conceitos de dialogismo - diálogo com diversas vozes - e de polifonia - as diversas vozes que compõem um todo no diálogo - partem da noção de que, ao enunciar, ainda que se utilizem vozes alheias, é possível, junto com elas, elaborar uma interlocução que fomente uma construção de pontos de vista. Isso fundamenta e apresenta a voz do autor, o qual assume a responsabilidade por suas enunciações. O conhecimento, dentro dessa reflexão, torna-se dialógico. 
Em qualquer enunciado quando estudado com mais profundidade em situações concretas de comunicação discursiva, descobrimos toda uma série de palavras do outro semilatentes e latentes, de diferentes graus de alteridade. ... 0 enunciado se verifica um fenômeno muito complexo e multiplanar se não o examinamos isoladamente e só na relação com o seu autor (o falante), mas como um elo na cadeia da comunicação discursiva e da relação com outros enunciados a ele vinculados ... (Bakhtin, 2010a, p. 299).

Neste contexto, dialogar, referenciar, buscar no pensamento alheio os pontos-chave para as construções autorais não impede a emissão de argumentos, críticas, oposições ou concordâncias. Ainda segundo Bakhtin e Volochinov (1995):

0 problema do diálogo ... torna-se mesmo o centro das preocupações em Linguística. Isso é perfeitamente compreensível, pois, como sabemos, a unidade real da língua ... não é enunciação monológica, individual e isolada, mas a interação de pelo menos duas enunciações, isto é, o diálogo (pp.145-146).

Dessa forma, autorar configura um quadro cíclico. Trata-se de constituir-se e constituir, fomentar um diálogo em que um raciocínio é completado e, ao mesmo tempo, permitir que, por meio dos questionamentos do pesquisador, o outro, sujeito-objeto de pesquisa, possa refletir, modificar-se, responder e completar seu outro e a si próprio na expectativa da construção de conhecimento.

Se, ao se aludir à educação, ao aprendizado, à busca pelo conhecimento; ou, ao se falar de formação de professores, fatalmente se soldam os elos por meio dos quais o pesquisador se constitui do outro, do pensamento, da voz do outro e vice-versa.

Bakhtin; Volochinov (1995), ao se referir ao "discurso de outrem", diz que "o discurso citado é o discurso no discurso, a enunciação na enunciação, mas é, ao mesmo tempo, um discurso sobre o discurso, uma enunciação sobre a enunciação” ( p. 144). Ainda que seja incorporado o texto de outrem em enunciados, não se apagam as marcas do outro e nem precisa ser apagada a própria voz do enunciador. Ambas podem se completar em caráter mútuo:

A enunciação do narrador, tendo integrado na sua composição uma outra enunciação, elabora regras sintáticas, estilísticas e composicionais para assimilá-la parcialmente, para associá-la a sua própria unidade sintática, estilística e composicional, embora 
conservando, pelo menos sob uma forma rudimentar, a autonomia primitiva do discurso de outrem, sem o que ele não poderia ser completamente apreendido (Bakhtin; Volochinov, 1995, p. 145).

Kramer (2007, p. 82), baseando-se em seus estudos sobre Bakhtin, delineia todo um pensamento acerca de autoria e autonomia, fazendo correspondências com elementos observados nas experiências vividas em escolas e indica uma série de fatores com os quais podemos dialogar, ao abordar autoria no espaço das universidades. Um dos pontos diz respeito às propostas pedagógicas para o trabalho com leitura e escrita. A autora diz que essas práticas privilegiam ou o polo da subjetividade ou o da objetividade, o que indica que ou se opera com a língua como um mero conjunto de sistemas, cerceando a exposição de sentimentos ou ideias, ou então se opera com a exclusiva expressão, de modo que certas regras, necessárias à construção do texto, sejam rejeitadas.

Complementando esse pensamento, Kramer (2007) elabora seu conceito de autor:

Ser autor significa produzir com e para o outro... Somente sendo autora a criança interage com a língua; somente sendo lida e ouvida pelos outros ela se identifica, diferencia, cresce no seu aprendizado... Somente sendo autora ela penetra na escrita viva e real, feita na história (p. 83).

Trazendo essas proposições para o âmbito das graduações, é possível que uma questão seja posta: estariam os licenciandos sendo autores, numa atitude ético-responsável, na emissão de seus dizeres dialógicos, permitindo a construção de saberes?

Além de as trocas dialógicas serem premissas para que haja conhecimento, não se pode esquecer de que, quando se constroem enunciados relacionados à pesquisa acadêmica, da mesma forma como outros tipos de discursos são construídos - narrações, relatórios, resenhas -, é primordial o entendimento da necessidade de se agir eticamente. Se há uma relação de alteridade no ato educativo, esse fato implica um agir ético que, aos olhos de Bakhtin (2010b), não permite álibis. É no aqui e no agora que os licenciandos devem agir eticamente como pensadores da educação, como sujeitos envolvidos nos debates que fomentam diálogos objetivados no fazer conhecer, nas trocas, no aprendizado profícuo, como nos define o próprio autor: 
0 ato responsável é, precisamente, o ato baseado no reconhecimento desta obrigatória singularidade. É essa afirmação do meu não álibi no existir que constitui a base da existência sendo tanto dada como sendo também real e forçosamente projetada como algo ainda por ser alcançado. É apenas o não álibi no existir que transforma a possibilidade vazia em ato responsável real (através da referência emotivo-volitiva a mim como aquele

que é ativo). É o ato vivo de um ato primordial ao ato responsável, e a criá-lo, juntamente com seu peso real e sua obrigatoriedade; ele é o fundamento da vida como ato, porque ser realmente na vida significa agir, é ser não indiferente ao todo na sua singularidade (Bakhtin, 2010a, p. 99).

Com base nesse pressuposto, o licenciando deve perceber a sua construção autoral pautada na ética, na busca pelo saber, compreendendo que uma pesquisa possui também um caráter de reverberação social. No caso dos professores dos cursos de licenciaturas, o ato ético se constitui de posturas de orientação dos trabalhos de pesquisa, acompanhamento deles, leitura efetiva das construções dos licenciandos, incentivando-os a serem autores e evitando deixar apenas nas mãos dos professores de disciplinas específicas de Metodologia do Trabalho Científico ou Pesquisa Acadêmica a responsabilização pela formação de pesquisadores.

Futuros professores devem ser sensibilizados sobre sua função mediadora na construção de saberes, de modo a incentivar movimentos de busca de autorias ético-responsáveis, desde as séries iniciais da escolarização.

\section{Síntese da metodologia empregada}

Nossa primeira preocupação, ao abordar o tema em foco, foi dar voz a professores e licenciandos de universidades públicas, privadas e confessionais, a pretexto de comparar suas colocações e associá-las a estudos e resultados de outras empirias que também analisaram questões referentes ao plágio e à autoria.

Dar voz aos professores permitiu compreender como eles estão se relacionando com as produções escritas de seus alunos, como elas estão sendo conduzidas e que paradigmas de combate ao plágio e de fomento à construção autoral têm ou não sido empregados.

Por outro lado, ouvir os relatos de alunos permitiu que compreendêssemos os porquês do plágio, as configurações de sua construção e as motivações que levam ao ato. 
Como ponto de partida, foram realizadas entrevistas semiestruturadas com 30 licenciandos e 9 professores universitários. As entrevistas tinham como linha norteadora temas como plágio/autoria, pesquisa, orientação e ensino de pesquisa. Esses temas e suas subdivisões constam de um manual de códigos criado para facilitar o tratamento dos dados, bem como mostrar em que contexto questões e respostas de entrevistas foram construídas. Essa etapa da metodologia minimizou as chances de interpretações equivocadas ou ambíguas das falas dos entrevistados.

Os dados produzidos foram analisados a partir de categorias como: conceito de plágio e autoria, motivações para citar, mecanismos de construção de plágio e autoria, orientação de professores e universidades sobre pesquisa e plágio.

Os dados foram organizados em tabelas, o que permitiu comparações e triangulações com empirias revisadas e referenciais teóricos que iluminam nossas proposições.

Para a redação final da dissertação, usamos pseudônimos, escolhidos pelos entrevistados, para garantir o anonimato, conforme acordo firmado em termo de compromisso assinado pelo pesquisador e pelos entrevistados. Todo o projeto de pesquisa, bem como o roteiro das entrevistas, foi submetido a um comitê de ética antes da entrada em campo.

\section{Resultados \\ Ocorrência e concepções de plágio}

Dezoito dos trinta licenciandos entrevistados cometeram alguma forma de plágio. Aqueles que declaram abertamente plagiar - nove licenciandos - justificam seu ato por falta de tempo, dificuldade de escrita, complicações no manejo da pesquisa, inocuidade dos trabalhos ou má conduta dos professores, o que se refere diretamente à falta de estímulo e de orientação para pesquisas.

Carolina: Talvez eu não soubesse que aquilo ali era errado [itálicos nossos]. E eu não sabia principalmente onde procurar, né? Porque assim, não, não tinham me ensinado ainda como eu fazia o negócio. Eu acho que é mais ou menos por aí. [desconhecimento do conceito de plágio].

Binho: Porque eu quis encontrar um meio fácil e rápido de terminá-lo (o trabalho). Não queria perder pontuação e foi um modo mais rápido de obter algo. [falta de tempo / trapaça para obter êxito] 
Foram nove os casos de plágio não intencional - situações em que o licenciando desconhece o que de fato configura o ato ilícito. Nesses casos, o licenciando usa paráfrases não referenciadas, acreditando que, a partir da transformação do pensamento alheio, passa a ter a posse dos dizeres utilizados.

\section{Concepções de plágio e autoria}

Tanto as respostas de professores como as dos licenciandos foram difusas, pouco claras, girando em torno de afirmações do tipo "plágio é a cópia integral de textos, ou um roubo do ponto de vista ético". Isso indica que o entendimento do conceito, para os dois grupos de participantes da empiria, se faz de modo insatisfatório diante das múltiplas possibilidades existentes, o que dificulta a detecção do plágio e as orientações sobre ele.

Em contrapartida, os grupos demonstraram afinidades na definição de autoria, denotando maior convicção do que seja autorar. Para ambos os grupos, as respostas giraram em torno de definições como: "ser autor é manter um diálogo com outros textos, mas apontando pontos de vista, críticas e inserções aos pensamentos estudados".

\section{Motivos para citar}

Dos 30 licenciandos entrevistados, 19 fazem citações para reforçar a argumentação e 19 apontam que citar a palavra de outrem legitima a voz autoral. A preocupação dos participantes se concentra em conseguir uma boa nota em sua construção escrita. Desse modo, o licenciando quer que o professor perceba que houve leitura de diversos autores. Dá-se uma importância maior ao que o professor espera ler e pouca atenção a uma exposição de ideias baseada em uma reflexão e em um posicionamento crítico.

Há professores que não esperam de seus licenciandos um posicionamento autoral:

Gustavo: Eu acho que na licenciatura eles posicionam ainda muito pouco. Não tenho certeza se tem que ser diferente. ... Uma dissertação de mestrado você espera que o aluno dialogue com diferentes autores sobre o tema. E em uma tese de doutorado, ele precisa ter um posicionamento original, pessoal sobre o tema. Então... eu não sei se é exigir pouco dos alunos. Mas eu fico bastante satisfeito quando eles conseguem entender bem o posicionamento do autor que ele está lendo, né? 
Esse tipo de compreensão por parte de professores indica que pouca importância tem sido dada à produção autoral dos licenciandos. Esse quadro deve ser alterado, se entendermos que um futuro professor, que não é dono dos seus dizeres, terá dificuldade de ensinar seus alunos como construir autorias autônomas.

\section{Relação entre orientação de pesquisa e plágio}

Neste item, buscamos responder ao questionamento: alunos que cometem plágio têm recebido orientações sobre os processos de preparação, elaboração e construção dos trabalhos de pesquisa por parte dos professores? Para tal, foi apresentado aos entrevistados o questionamento: seus professores de sala de aula ensinam o passo a passo do processo de construção de um trabalho de pesquisa?

Dos 18 licenciandos que cometem algum tipo de plágio ( 9 intencionalmente e 9 sem intenção), 10 apontam que os professores não têm ensinado pesquisa. Em seguida, percebemos que 8 licenciandos disseram aprender pesquisa em disciplinas específicas, oferecidas ou muito no início dos cursos, ou por volta do 5ำ ou 6ำ períodos. Quando ministradas no início da graduação, os licenciandos deixam, nos períodos seguintes, de manter um contato com as normas técnicas e preceitos éticos necessários a um processo de pesquisa, uma vez que os professores de períodos seguintes, por acreditarem que seus alunos possuem conhecimento prévio do que seja o fazer acadêmico relativo à pesquisa, deixam de retomar as informações, abrindo, de certo modo, espaço para a construção do plágio. Quando oferecidas em períodos já adiantados, como o $5^{ }$ou 6은, o espaço entre $1^{\circ}$ e $5^{\circ}-$ ou $6^{\circ}$ período - fica aberto e livre para a realização do plágio.

Acerca das dez ocorrências declarando que os professores não ensinam pesquisa, é preciso entender que, neste caso específico, os licenciandos estão levando em consideração professores de disciplinas regulares e não os das específicas de Metodologia do Trabalho Científico, Pesquisa Acadêmicas e afins.

Camila: Eu acho que isso não é muito bem orientado. Você mesmo constrói uma pergunta e vai responder aquele tema... Eu acho que isso é uma coisa que a gente aprende mais fazendo. É... eu vejo que desde que eu entrei na faculdade a qualidade dos meus trabalhos melhorou, mas por causa da experiência [itálicos nossos]. Não por orientação. Eu me sinto um pouco desorientada nesse sentido.

A pretexto de se contrastarem as informações acima apresentadas, confronta- 
mos os dados dos licenciandos com as declarações dos nove professores entrevistados. Percebemos que as declarações são bastante distintas e vagas, quando a questão é: como você orienta um trabalho de pesquisa? Há professores que declaram orientar conteúdo, outros alegam indicar formato do trabalho de acordo com as normas da ABNT. Há quem acredite que orientar seja apenas indicar fontes. Há ainda os que declaram não orientar pesquisa, justificando-se com o fato de existirem nas universidades cursos específicos de Metodologia do Trabalho Científico, ou Pesquisa Acadêmica.

Beija-Flor: Toda quarta-feira eu tô lá... com meu computadorzinho aberto, cada um senta, a gente faz, eu salvo no computador e mando pra eles por e-mail. ... E aí eles vão trazendo as dificuldades: "Beija-Flor, olha, achei esse texto... tá muito dificil... o que é que você acha e tal...!" [itálicos nossos] ... Então, esses últimos dias que vão se aproximando da entrega, aí é um tal de aparecer... tanto que nessa última correção eu mandei e-mail pra eles dizendo: "Olha, não estou mais verificando os últimos", né? Já eram oito horas da noite de domingo. Eu disse: "Não estou mais verificando se é cópia, né? É... só vou fazer isso agora no dia da entrega. Dia seis. Se for copiado, zero"!

Ana Terra: A gente tem que mostrar para eles as normas da ABNT, como que eles têm que fazer. ... Pelo menos aqui, com o nosso aluno, quando você fala em trabalho monográfico, trabalho acadêmico, artigo cientifico, eles já ficam assim: "Mas o que... que é isso"?

Gustavo: Não. Não. Não faço porque é... geralmente eles têm uma disciplina que é Pesquisa Educacional, na qual eles deveriam aprender a fazer isso e, também, vou pressupondo que eles vão aprendendo isso na própria leitura dos textos, né? Conforme ele vai lendo o texto acadêmico e ele vai vendo como que o autor que ele tá lendo, estudando, cita outros autores, porque em geral os autores citam outros autores, eu acredito que ele vá aprendendo um pouco.

Cabe ressaltar que apenas duas das universidades participantes da empiria apresentam cartilhas ou links em suas homepages tentando instruir os alunos acerca do plágio. Contudo, há professores dessas universidades que não conhecem o material de orientação, assim como nenhum aluno dessas mesmas universidades teve contato com o material informativo, o que indica que o processo não tem atingido seu objetivo. 


\section{Verificação de plágio}

A verificação do plágio também é uma questão polêmica, uma vez que há professores que consideram esse mecanismo como sendo um ato de policiamento. No entanto, como o plágio não se configura apenas como uma trapaça, mas pode ser também cometido por desconhecimento ou lapsos durante a escrita dos trabalhos, verificar plágio se torna um ato educativo. É preciso saber se o licenciando plagia por comodismo ou se ele desconhece o ato ilícito e seus modos de configuração. Se o professor não verifica, como poderá orientar, indicar caminhos de mudança?

Partindo dessas colocações, qual é o problema real que impede que licenciandos sejam autores e autônomos na veiculação de seus dizeres? Como operar com o uso do discurso de outrem de modo a promover diálogos que propiciem uma escrita autoral nos textos de pesquisa, evitando um modelo de mera repetição de ideias, ou ainda, fazendo com que as citações não sejam apenas formalidades do universo acadêmico? Como lidar com a formação de professores não autores que operarão com leitura e escrita em nossas escolas? E o professor universitário? Qual o papel desse formador diante de todos esses dilemas?

\section{Caminhos propostos para a minimização do problema}

São muitas as indagações e difíceis os caminhos para lidar com o problema que se situa na fronteira entre plágio e autoria. Contudo, acreditamos ser possível amenizar esse quadro, se alguns pontos forem observados: a) deve o licenciando receber de seus professores as devidas oportunidades de ler, falar, escrever; b) devem existir nos cursos de formação de professores espaços para um acompanhamento sistemático da produção escrita do aluno, de modo que a técnica de texto de pesquisa não ofusque o brilho dos dizeres que vêm de um entendimento essencial e que está na gênese do conhecimento; c) precisa o professor saber dar os comandos, pois isso modifica o que o aluno escreve e a qualidade de tal construção escrita; d) necessita o professor olhar com seriedade para aquilo que o aluno escreve, isso faz com que ele perceba seu valor como autor e passe a cuidar com maior zelo de seus ditos; e) deve a universidade trabalhar a construção de autorias, propor diálogos com diversas vozes, a polifonia bakhtiniana, mas apropriar-se dessas vozes de forma adequada e ética; f) carece o professor perceber que verificar o plágio deve ser um ato entendido como educativo e não de mero policiamento, uma vez que há alunos que cometem o plágio sem saber que, de fato, estão envolvidos numa construção ilícita de dizeres; g) 
devem as universidades ampliar as discussões sobre autoria e plágio, fortalecer sua divulgação e solicitar que cada professor, ao pedir trabalhos, delimite suas regras, seus objetivos, colocando para o aluno responsabilidades de cunho ético e autoral.

Assumir compromissos de formar autores pode ser uma medida que impeça, futuramente, ouvir relatos como o que se segue:

Pesquisador: A senhora me falou uma coisa importante: essa questão de ler os trabalhos de cada um dos alunos e respeitar o aluno, respeitar aquilo que ele construiu. E pelas suas observações entre os colegas, a senhora sente que eles se mobilizam para isso? [itálicos do autor].

Ana Terra: Não, não. E muitos dizem abertamente! ... Então ele diz assim: “Ah eu olho assim: vejo a capa e pronto! Vejo... se está bonitinho eu dou a nota. Não dou dez pra ninguém!", para não desconfiar que não leu [itálicos do autor]. Então, entre os colegas, existem professores que não leem mesmo, né? ... Eu ainda sento e leio tudinho. Faço as anotações... mas tem colega que não, que não lê.

\section{Considerações finais}

Neste trabalho tratamos de vozes diluídas, camufladas ou exaltadas. 0 debate se concentra no fato de que o plagiário, ao exaltar enunciados alheios, acaba por diluir sua própria fala, camuflando-se atrás da voz do outro. Diante dessa premissa, entendemos que o licenciando que plagia e não consegue autorar enfrentará um árduo caminho ao ensinar seus alunos a terem voz. Assim, discutir plágio no âmbito dos cursos de licenciaturas se torna uma premissa para a formação do caráter ético do futuro professor que operará com pesquisa em seu exercício da docência.

A empiria mostrou que professores e licenciandos têm a noção de que plágio é algo reprovável e antiético, contudo, quando incitados a pensar sobre o assunto, acabam por se perder em trilhas diversas. De modo sintético, sabe-se o que é autorar, mas não há clareza no entendimento do que seja plágio.

Preocupa-nos em especial, o licenciando que comete plágio não intencional. Esse acredita ser autor de seus dizeres, não reconhece suas atitudes como plágio e, vindo a ser professor, em um futuro próximo, talvez dê continuidade a um ciclo de desconhecimento e de conduta não autoral. O licenciando que assume plagiar sabe que sua ação é ilegal, antiética e que possui consequências. Contudo, nesse caso, sempre 
existirá a opção de plagiar ou não. A este tipo de plagiário também devemos nossa atenção pedagógica, no sentido de ajudá-lo a encontrar e a valorizar a sua voz, expondo-a de modo a respeitar os preceitos normativos da integridade acadêmica.

Aos professores dos cursos em questão, cabe uma atenção diferenciada no que concerne ao fomento à construção autoral e à verificação de plágio. Isso porque apenas aferindo se o aluno plagia - intencional ou não intencionalmente - será possível tratar o tema como ato educativo, buscando caminhos de sensibilização, orientação e punição nos casos de reincidência no plágio.

A sala de aula, independentemente do momento do curso ou da disciplina cursada, precisa ser o solo inicial para o debate. Este, por sua vez, deve se estender a todas as hierarquias da academia, de modo a se pensarem estratégias, políticas internas; a criar comissões que possam debater, analisar casos de plágio; a propor situações propícias para a construção de autorias, bem como ferramentas de orientação que, de fato, se tornem de conhecimento de alunos e professores.

Sugerimos um acompanhamento mais efetivo do processo de pesquisa dos licenciandos, um contato mais próximo com a escrita deles - para ajudar a inibir a ação do plagiário -, a modificação da forma de estimular pesquisas, exigindo não apenas definições de conceitos, mas solicitando ao estudante críticas, pontos de vista, de modo a provocar a construção autoral.

É preciso que o licenciando entenda que sua voz é importante e que a virtude de autorar não se encontra apenas nas mãos de doutorandos, professores universitários ou acadêmicos de renome. Acreditamos que todos podem ser autores, a partir do momento em que são levados à prática da escrita, de modo que se una um pensamento a uma técnica.

Talvez a percepção mais instigante originada a partir desta investigação seja a hipótese de que o ato ilícito do plágio pode ser tão construído quanto a autoria. Assim, a falta de rigor no fomento à autoria pode promover a realização do plágio.

Cabe ressaltar que há professores preocupados com o assunto e que fazem trabalhos dignos de registro; contudo, ainda há muito a fazer e a refletir. Assim, nós, estudiosos da Educação, pesquisadores, professores universitários, devemos assumir nossa parcela de responsabilidade neste processo da formação e constituição autoral. Portanto, permitir que vozes se calem, camuflem-se ou se diluam por intermédio do plágio é ser conivente com uma educação debilitada e com uma ciência fadada ao fracasso. 


\section{Referências bibliográficas}

Amorim, M. (2004). O pesquisador e seu outro: Bakhtin nas Ciências Humanas. São Paulo: Musa.

Bakhtin, M. (2010a). Estética da criação verbal. São Paulo: Martins Fontes.

Bakhtin, M. (2010b). Para uma Filosofia do ato responsável. São Carlos: Pedro e João Editores.

Bakhtin, M., \& Volochinov, V. N. (1995). Marxismo e filosofia da linguagem. São Paulo: Hucitec.

Barbastefano, R. G \& Souza, C. G. de. (2007, dezembro). Percepção do conceito de plágio acadêmico entre alunos de engenharia de produção e ações para sua redução. Revista produção Online. (ed. especial). ISSN 1676-1901. Recuperado em 27 de julho de 2011, de http://producaoonline.org.br/index.php/rpo/article/ view/52/52.

Barthes, R. (2004). A morte do autor. In O rumor da língua. São Paulo: Martins Fontes.

Ferreira, A. B. de H. (2001). Miniaurélio século XXI escolar: o minidicionário da língua portuguesa (4a ed. ver. ampl.). Rio de Janeiro: Nova Fronteira.

Foucault, M. (2002). O que é um autor. Lisboa: Passagens; Veja.

Foucault, M. (2009). A ordem do discurso (19a ed.). São Paulo: Loyola.

Kramer, S. (2007). Por entre as pedras/arma e sonho na escola (3a ed.). São Paulo: Ática.

Krokoscz, M. (2012). Autoria e plágio: um guia para estudantes, professores, pesquisadores e editores. São Paulo: Atlas.

Leite, E. L. (2009). Plágio e outros estudos em direito de autor. Rio de Janeiro: Lumen Juris.

Machado, J. P. (1967). Dicionário etimológico da língua portuguesa (2a ed.). Lisboa: Confluência.

Orlandi, E. P. (1996). Interpretação: autoria, leitura e efeitos do trabalho simbólico. Petrópolis, RJ: Vozes.

Park, C. (2003 October). In other (People's) words: plagiarism by university students literature and lessons. In Assessment \& Evaluation in Higher Education, 28(5), 471-488. Recuperado em 22 de dezembro de 2011, de http://www.lancs.ac.uk/ staff/gyaccp/caeh_28_5_02lores.pdf>. 
Vasconcelos, S. M. R. (2012, setembro). O plágio na comunidade científica: questões culturais e linguísticas. Ciência e Cultura, 59(3). Recuperado em 20 de setembro, de <http://cienciaecultura.bvs.br/scielo.php?script=sci_arttext\&pid=Sooo9 $7252007000300002 \& \operatorname{lng}=e n \& n r m=i s 0\rangle$.

Submetido à avaliação em 17 de setembro de 2013; aprovado para publicação em 29 de maio de 2014. 